\title{
Pengaruh Penambahan Leri dan Enceng Gondok, Klaras, Serta Kardus Terhadap Produktivitas Jamur Merang (Volvariella volvacea) pada Media Baglog
}

\author{
Suparti, Aninda Ayu Kartika, Devi Ernawati \\ Prodi P. Biologi FKIP Universitas Muhammadiyah Surakarta \\ Jl. A. Yani Tromol Pos 1 Pabelan Kartasura Surakarta 57162
}

sup168@ums.ac.id

\begin{abstract}
Abstrak
Jamur merang merupakan jamur pangan yang pertumbuhanhannya memerlukan media mengandung selulosa, hemiselulosa dan lignin. Limbah organik tersebut yaitu Leri,klaras, kardus dan enceng gondok. Tujuan penelitian ini untuk mengetahui pengaruhpenambahan leri dan Limbah Organik (klaras,kardus dan eceng gondok) terhadap produktivitas jamur merang pada media baglog. Penelitian menggunakan rancangan acak lengkap (RAL) pola faktorial dengan 2 faktor dan 3 ulangan. Faktor 1 volume leri: (L1)50 ml dan (L2)100 ml. Faktor 2 jenis Media : (M1) Klaras, : (M2) Kardus, dan (M2) Enceng gondok.. Parameter yang diukur adalah berat basah badan buah jamur merang. Hasil analisis sebagai berikut: produksi jamur merang yang ditumbuhkan dalam baglog yangditambahkan limbah organik terdiri atas klaras, kardus dan enceng gondok, hasil yang terbaik, yaitu pada perlakuan: $\mathrm{M}_{1} \mathrm{~L}_{2}$ (klaras $125 \mathrm{~g}$ dan penambahan air leri $100 \mathrm{ml}$ ) yaitu 67,51 g, M2L2 (media kardus dengan penambahan air leri $100 \mathrm{ml}$ ) yaitu 75,00 g dan perlakuan M3L1 (enceng gondok $125 \mathrm{~g}+$ leri $50 \mathrm{ml}$ ), yaitu $76,67 \mathrm{~g}$. Sedangkan berat tubuh buah jamur merang paling rendah pada perlakuan $\mathrm{M}_{1} \mathrm{~L}_{0}$, yaitu 61,67 g, M2L0 (media kardus tanpa penambahan air leri) yaitu 56,67 g, dan M3L0 yaitu 60,67 g.
\end{abstract}

Kata Kunci:, leri, Eceng gondok, klaras, kardus, produktivitas jamur merang

\section{PENDAHULUAN}

Jamur merupakan organisme tidak berkhlorofil yang mempunyai empat sifat yaitu, heterotrop, saprofit, mutualistik dan parasit. Ada dua macam jamur jika dilihat dari aspek komsumsi, yaitu jamur yang beracun dan jamur yang dapat dimakam. Jamur pangan, misalnya jamur merang, jamur kancing, jamur tiram, jamur linchi, jamur sintakhe Jamur merang merupakan salah satu di antara sekian banyak spesies jamur tropis dan subtropis yang banyak dikenal dan diminati oleh masyarakat. Pembudidayaan jamur merang sebagai makanan bergizi telah lama dilaksanakan namun produksinya masih belum bisa menutupi kebutuhan konsumen. Kandungan gizi dalam jamur merang adalah karbohidrat 8,7 \%, protein 26,49 $\%$, lemak $0,67 \%$, kalsium 0,75 \%, fosfor $30 \%$, kalium 44,2 \% dan vitamin. Gender
(1982) menambahkan bahwa mineral yang terkandung dalam jamur merang lebih tinggi dibandingkan dengan yang terkandung dalam daging sapi dan domba.Setiap jenis jamur memerlukan syarat tumbuh yang berbeda-beda. Jamur merang merupakan jamur yang tumbuh di daerah tropika dan membutuhkan suhu dan kelembaban yang cukup tinggi berkisar antara $30^{\circ} \mathrm{C}$ samapai dengan $38^{\circ} \mathrm{C}$ dalam krudung atau kubung. Kelembaban relatif yang diperlukan adalah berkisar antara $80 \%$ sanpai dengan $85 \%$ serta kebutuhan akan $\mathrm{pH}$ media tumbuh berkisar antara $\mathrm{pH}$ 5,0 sd $\mathrm{pH} 8,0$ (Sinaga, 2001).

Tubuh buah jamur merang yang masih muda berbentuk bulat telur sedangkan apabila sudah tua tudung jamur merang akan mengembang seperti payung, pada saat masih muda tubuh 
buah berwarna cokelat gelap hingga abu-abu dan dilindungi selubung. Pada tubuh buah jamur merang tua, tudung berkembang seperti cawan berwarna coklat tua keabu-abuan dengan bagian batang berwarna cokelat muda. Jamur merang mampu bertahan hidup pada suhu yang relative tinggi, antara $30-$ $38^{\circ} \mathrm{C}$ dengan suhu optimum pada $35^{\circ} \mathrm{C}$ (Widiyastuti, 2008). Jamur merang biasanya hidup bergerombol dan dapat bertahan hidup pada jerami padi, sagu, serbuk gergaji, dan tandan kosong kelapa sawit (Gunawan, 2011).

Produksi jamur merang sangat dipengaruhi oleh media tempat jamur merang tumbuh, karena jamur tidak dapat berasimilasi dan tergolong jasad heterotropik sehingga untuk keperluan hidupnya tanaman jamur mempunyai ketergantungan pada sumber nutrisi (Nurman dan Kahar, 1990). Sumber nutrisi dapat diberikan kepada media atau didapatkan langsung dari media tersebut. Media tersebut berupa limbah organik, misalnya air cucian beras, jerami, limbah kapas, ampas batang aren, eceng gondok, kardus, ampas tebu, sabut kelapa, daun pisang kering atau klaras, serbuk gergaji, alang-alang dan lainnya.

Tahap perkembangan jamur merang dibagi menjadi tiga tahap yaitu tahap pertumbuhan miselium, tahap pembentukan tubuh buah dan tahap pelepasan spora (Widiastuti,2008). Kehidupan jamur merang berawal dari spora (basidiospora) yang kemudian akan berkecambah membentuk hifa yang berupabenang-benanghalus. Hifainiakan tumbuh keseluruh bagian media tumbuh, Kemudian dari kumpulan hifa atau miselium akan terbentuk gumpalan kecil seperti simpul benang yang menandakan bahwa tubuh buah jamur mulai terbentuk. Simpul tersebut berbentuk bundar atau lonjong dan dikenal dengan stadia kepala jarum (pinhead) atau primordia. Simpul ini akan membesar dan disebut stadia kancing kecil (small button). Selanjutnya stadia kancing kecil akan terus membesar mencapai stadia kancing (button) dan stadia telur (egg). Pada stadia ini tangkai dan tudung yang tadinya tertutup selubung universal mulai membesar. Selubung tercabik, kemudian diikuti stadia perpanjangan (elongation). Cawan (volva) pada stadia ini terpisah dengan tudung (pileus) karena perpanjangan tangkai (stalk). Stadia terakhir adalah stadia dewasa tubuh buah (Sinaga, 2005).

Pada stadia kancing yang telah membesar akan terbentuk bilah. Bilah yang matang akan memproduksi basidia dan basidiospora, kemudian tudung membesar. Pada waktu itu, selubung universal yang semula membungkus seluruh tubuh buah akan tercabik. Tudung akan terangkat keatas karena memanjangnya batang, sedangkan selubung universal yang sobek akan tertinggal dibawah dan disebut cawan.

Berdasarkanpenelitianyangdilakukan oleh Ruhama (2014) menunjukkan bahwa adanya perbedaan kadar besi dan kalsium antara jamur merang dan jamur tiram. Kadar zat besi paling tinggi terdapat pada jamur merang sedangkan kadar kalsium paling tinggi terdapat pada jamur tiram. Adapun kadar besi pada jamur merang dan jamur tiram berturutturut yaitu $(0,6389 \pm 0,0959) \mathrm{mg} / 100 \mathrm{~g}$ dan $(0,5055 \pm 0,0207) \mathrm{mg} / 100 \mathrm{~g}$. kadar kalsium pada jamur merang dan jamur tiram berturut-turut yaitu $(1,0584 \pm 0,2058)$ $\mathrm{mg} / 100 \mathrm{~g}$ dan $(4,2760 \pm 1,3964) \mathrm{mg} / 100 \mathrm{~g}$.

Selain memiliki kandungan nilai gizi yang sangat bermanfaat bagi tubuh manusia, jamur merang mengandung zat yang bersifat obat seperti Volvatoksin dan flammutoksin (cardiac tonic) (Suriawiria, 1997). Jamur merang juga mengandung senyawa eritadenin yang berkhasiat 
sebagai anti racun dan mengandung sejenis antibiotik yang berkasiat mencegah kurang darah (anemia), kanker dan menurunkan tekanan darah tinggi.

\section{Media Pertumbuhan Jamur Merang}

Pada umumnya media tumbuh jamur merang yaitu jerami padi, dan di tumbuhkan pada bedengan atau tidak dalam baglog sebagaimana jamur pangan lainnya. Jerami padi merupakan limbah organik yang lazim digunakan sebagai media tumbuh jamur merang. Jerami mengandung selulosa 2,98 \% dan garam mineral (N, P, K). Pemakaian jerami padi sebagai media tumbuh jamur merang sebenarnya sangat baik untuk media jamur merang, mengingat jumlahnya banyak, murah mudah didapatkan, mudah di campur dengan bahan-bahan pelengkap nutrisi, tetapi jerami padi hanya di temukan pada musim panen saja. Di samping itu jerami padi saat ini relatif mahal dan agak sulit didapatkan, karena semakin sempitnya lahan pertanian, oleh karena itu perlu adanya alternatif pengganti jerami, sebagai media tumbuh jamur, misalnya kertas kardus, daun pisang kering (klaras) dan enceng gondok. Maka untuk mengantisipasi hal tersebut perlu di cari media alternatif untuk pertumbuhan jamur merang . Alternatif tambahan yang di gunakan sebagai media tambahan jamur merang adalah dengan memanfaatkan tanaman eceng gondok, kardus dan klaras.

Media pertumbuhan jamur merang ditujukan sebagai penyedia nutrisi bagi pertumbuhan serta produktifitas jamur merang.

Bahan Dasar media pertumbuhan jamur merang meliputi : Jerami padi, Limbah batang aren (onggok), Kapur, Bekatul(dedak), Effectivemicroorganisme (EM-4), Air. Pada penelitian ini ditambahkan limbah organik.
1. Eceng gondok saat ini masih dimanfaatkan sebagai briket, pupuk, kompos, pupuk cair, pakan ternak, kerajinan tangan, bahan pembuat kertas dan bahan pembuat etanol. Kandungan hemiselulosa dan selulosa yang cukup tinggi serta kemampuan berkembang biak yang sangat cepat, adaptasinya yang tinggi terhadap lingkungan, sehingga mudah diperoleh sepanjang tahun, membuat eceng gondok berpotensi digunakan sebagai bahan tambahan pada media tanam untuk budidaya jamur merang.Kandungan Eceng Gondok Dalam 100\% Berat Kering, yaitu 30-55\% Selulosa dan 64,51\% Hemiselulosa (Kriswiyanti Dan Endah, 2009).

2. Air cucian beras (Leri)

Air leri merupakan air bekas pencucian beras yang mengandung banyak nutrisi yang terlarut di dalamnya. Menurut Puspitarini (2011), air leri memiliki kandungan nutrisi diantaranya karbohidrat berupa pati sebesar $89 \%-90 \%$, protein glutein, selulosa, hemiselulosa, gula dan vitamin $B$ yang banyak terdapat pada pericarpus dan aleuron yang ikut terkikis.Kandungan nutrisi beras yang tertinggi terdapat pada bagian kulit ari yang ikut bersama air cucian. Sekitar 80\% vitamin B1, 70\% vitamin B3, 90\% vitamin B6, 50\% mangan (Mn), 50\% Fosfor (P), 60\% zat besi (Fe), 100\% serat, dan asam lemak esensial (Munawaroh, 2010). Unsur hara fosfor diperlukan oleh jamur untuk membentuk bagian-bagian vegetative seperti tudung, tubuh jamur, dan akar (Warisno dan Dahana, 2010).Enceng gondok Karena dalam $100 \%$ berat keringnya, eceng gondok memiliki kandungan hemiselulosa mencapai 30-55\% (Nigam, 2002) dan 
selulosa 64,51\% (Kriswiyanti dan Endah, 2009). Sedangkan air leri mengandung mineral, vitamin B1, B12, unsur hara N, P.

C Klaras merupakan bagian dari tanaman pisang yang keberadaanya belum diperhatikan padahal mengandung hemiselulosa tinggi sehingga dapat dijadikan media tanam jamur. Dari hasil penelitian Nelson (2008), nutrisi daun pisang terdiri dari nitrogen 2,8-3,1\%; fosfor $18-0,21 \%$; kalsium $0,6-1 \%$; sulfur 0,22 0,25\%; kalium 3,2-3,5\%.

Berdasakan uraian tersebut di atas perlu dilakukan penelitian yang bertujuan utuk mengetahui: 1) Pengaruh media tumbuh limbah organik (penambahan air leri dan eceng gondok, klaras, serta kardus) dalam meningkatkan pertumbuhan miselium jamur merang pada media baglog. 2) Pengaruh media tumbuh limbah organik (penambahan leri dan eceng gondok, klaras, serta kardus) dalam meningkatkan jumlah badan buah jamur merang pada media baglog. 3)Pengaruhmedia tumbuh limbah organik (penambahan leri dan eceng gondok,klaras, serta kardus) dalam meningkatkan produktivitas jamur merang pada media baglog

\section{METODE PENELITIAN}

Penelitian dilakukan di laboratorium jamur Prodi P. Biologi FKIP-UMS, pada Agustus 2015 sampai dengan Mei 2016. Variabel Penelitian, yaitu variabel bebas: limbah organik (penambahan air leri, daun klaras, dan eceng gondok dan variabel terikat: produktivitas jamur merang. Alat yang digunakan yaitu alatalat untuk fermentasi, pembuatan log, sterilisasi,inokulasi, merawat jamur tiram putih dan pembuatan media. Sedangkan bahan yang digunakan yaitu:serbuk kayu sengon $100 \%$ (200g), bekatul 10\% (20g), Calcit (), 4\% (8g), dan air 70\% terhadap masing-masing perlakuan pada 1 baglog, gas, dan air, alkohol 70\%.

Pelaksanaan penelitian ini ada beberapa tahapan, yaitu: 1) tahap persiapan dengan melakukan fermentasi media yang digunakan selama dua- tiga hari, selanjutnya hasilnya dimasukkan kedalam baglog $(3 \mathrm{~kg})$, bagian atas kantung plastik diberi cincin paralon dan ditutup dengan kapas. 2) Sterilisasi, dilakukan menggunakan autoklaf dengan suhu $121^{\circ}$ selama 15 meni. Media yang telah disterilkan kemudian didinginkan selam 24 jam agar bibit yang ditanam tidak mati. 3) Setelah dingin maka dilakukan inokulasi bibit jamur tiram dan diinkubasikan ke dalam ruang inkubasi yang diatur suhu $\left(20-23^{\circ} \mathrm{C}\right)$ dan kelembabannya. 4) Pemeliharaan dilakukan dengan suhu berkisar antara 18-20 C dengan kelembaban 80-90\%. Menyiram kumbung menggunakan air bersih agar kelembaban tetap terjaga. Diamati dan dicatat waktu yang diperlukan dari munculnya miselium sampai pertumbuhan miselium optimum $\quad(100 \%$ baglog ditumbuhi miselium).Pengamatan dilakukan untuk melihat pertumbuhan miselium (hari), pertumbuhan jamur per 3 hari dengan indikator pertumbuhannya mencapai $30 \%, 60 \%$ dan $100 \%$.

Dalam penelitian ini menggunakan rancangan acak lengkap (RAL) pola faktorial yang terdiri dari 2 faktor yaitu, 1 Faktor 1: volume air leri $0 \mathrm{ml}$ (L0), air leri $50 \mathrm{ml}$ (L1), dan volume air leri 100 ml (L2) dan Faktor 2: Limbah pertanian: Enceng gondok (M1), klaras (M2), dan (M3) kardus. Masing-masing perlakuan dengan 2 kali ulangan. Parameternya yaitu, berat basah tubuh buah jamur merang (g). Tubuh buah jamur yang siap panen yaitu berumur 4-6 hari dari saat 
mulai tumbuh bakal jamur sampai jamur tumbuh besar, dicabut dan dibersihkan dari media tanam. Ditimbang, diamati dan dicatat berat keseluruhan jamur tiram pada panen I dan II. Data di analisis dengan analisis Diskripstif Kualitatif.

\section{HASIL DAN PEMBAHASAN}

Rerata berat basah jamur merang dengan penambahan limbah organik (enceng gondok, klaras, dan kardus) sebanyak $125 \mathrm{~g}$, dan air cucian beras (leri) $0 \mathrm{ml}, 50 \mathrm{ml}, 100 \mathrm{ml}$ dari panen ke-1 dan panen ke-2grafi 1.

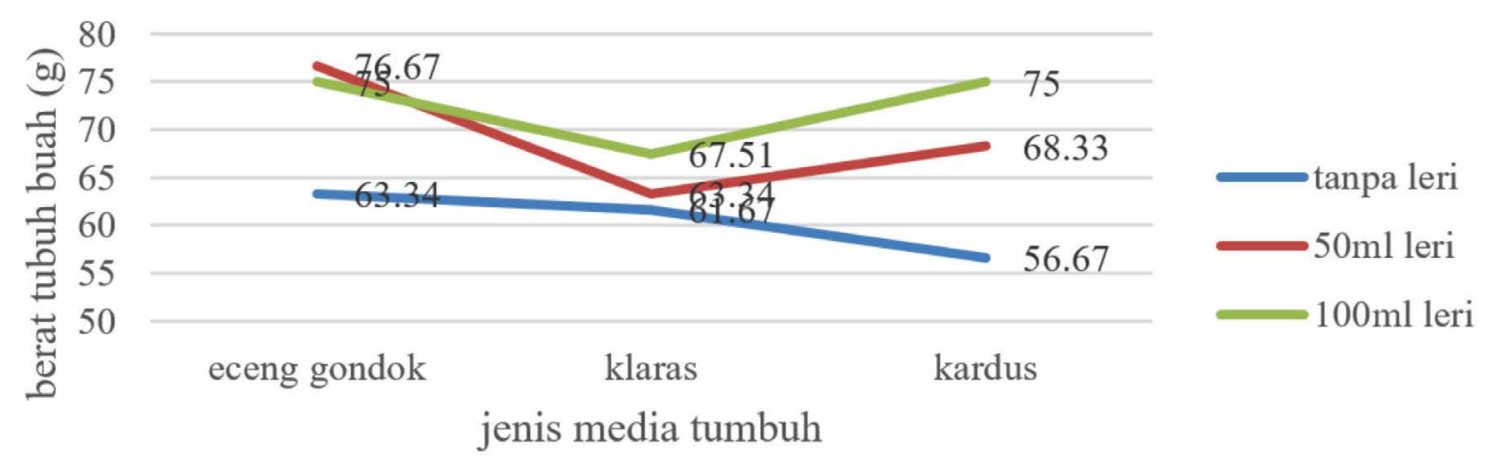

Grafik 1. Rerata berat tubuh buah jamur merang (g) dengan perlakuan penambahan jenis media pertanian dan air leri.

Pada grafik.1 diperoleh hasil berat tubuh buah jamur merang terbaik yaitu, perlakuan $\mathrm{M}_{1} \mathrm{~L}_{2}$ (klaras $125 \mathrm{~g}$ dan penambahan air leri $100 \mathrm{ml}$ ) yaitu 67,51 $\mathrm{g}$, sedangkan berat tubuh buah jamur merang paling rendah yaitu perlakuan $\mathrm{M}_{1} \mathrm{~L}_{0}$, yaitu $61,67 \mathrm{~g}$. Hal ini dimungkinkan karena klaras mengandung Selulosa 20,5$23,5 \%$, hemiselulosa 17,1-24,2 \%, dan lignin4,5-10,4\% (Wina (2001). Komponen tersebut dapat sebagai nutrisi tambahan yang membantu untuk pertumbuhan berat tubuh buah jamur merang.

Sedangkan leri terdapat kandungan zat yang mendukung dalam produktivitas berat tubuh buah jamur merang, yaitu fosfor, nitrogen, kalsium, vitamin B1, carbon, dan sulfur. leri merupakan air bekas pencucian beras yang mengandung banyak nutrisi yang terlarut di dalamnya. Menurut Puspitarini (2011), air leri memiliki kandungan nutrisi yaitu, karbohidrat berupa pati sebesar $89-90 \%$. Munawaroh, 2010, air leri mengandung $80 \%$ vitamin B1, 70\% vitamin B3, 90\% vitamin $\mathrm{B} 6,50 \%$ mangan (Mn), 50\% Fosfor (P), 60\% zat besi (Fe), 100\% serat, dan asam lemak esensial.

Unsur hara fosfor diperlukan oleh jamur untuk membentuk bagianbagian vegetative seperti tudung, tubuh jamur, dan akar (Warisno dan Dahana, 2010). Karbon (C) sebagai unsur dasar pembentukan sel dan sebagai sumber energi untuk metabolisme sel. Nitrogen diperlukan dalam sintesis protein, untuk pembentukan lemak serta berguna untuk mempercepat pertumbuhan jamur. Vitamin diperlukan sebagai katalisator dan bahan tambahan atau suplemen sehingga pertumbuhan jamur menjadi lebih baik. (Djariyah dan Djariyah 2011 dalam Kalsum, 2011). Mayun (2007), daun pisang merupakan media tubuh yang terbaik bagi pertumbuhan jamur merang, Data tersebut juga di dukung oleh penelitian Suparti dan Pakarti Arum Kinasih (2015), bahawa penambahan klaras (250 g) dan leri (50 $\mathrm{ml})$ dapat meningkatkan produktivitas jamur merang dalam baglog. 


\section{Pertumbuhan jamur merang pada media Kardus.}

Berdasarkan grafik 1 diperoleh hasil perlakuan terbaik berat tubuh buah jamur merang adalah perlakuan M2L2 (media kardus dengan penambahan air leri $100 \mathrm{ml}$ ) yaitu $75,00 \mathrm{~g}$, sedangkan berat tubuh buah jamur merang paling rendah adalah perlakuan M2L0 (media kardus tanpa penambahan air leri) yaitu 56,67 g. Hal ini dimungkinkan kardus sebagai produk olahan dari kayu, yang mengandung selulosa yang sangat diperlukan untuk jamur tumbuh. Hasil tersebut selaras dengan penelitian Suparti dan Pramita Restu Murti (2015), bahwa ada pengaruh penambahan media (kardus375 g) dan air leri $(50 \mathrm{ml})$ terhadap berat tubuh buah dan jumlah tubuh buah jamur merang. Hal itu dimungkingkan karena kardus merupakan produk olahan dari kayu sehingga kardus memiliki kandungan selulosa yang tinggi dan air leri terdapat kandungan nitrogen, karbohidrat (selulosa dan glukosa), vitamin B1, carbon, dan sulfur semua zat tersebut sebagai pendukung pertumbuhan jamur merang. Selulosa merupakan faktor terpenting yang dibutuhkan dalam pertumbuhan jamur merang.

Kardus dan leri sangat berpengaruh dalam pertumbuhan berat tubuh buah jamur merang karena kedua bahan tambahan tersebut sama-sama mengandung selulosa dan sama-sama menambah unsur hara dalam pertumbuhan jamur merang, sehingga dapat membantu pertumbuhan berat tubuh jamur merang. Kandungan nutrisi pada setiap baglog yang berbeda menyebabkan berat tubuh buah jamur merang tiap baglog berbeda.
Hasil ini didukung oleh Suharjo (2010) Memanfaatkan kardus bekas menjadi media tanam jamur merang menjadi alternatif bisnis jamur yang dilipih beberapa orang karena jamur merang yang dihasilkan ternyata lebih bagus dan lebih berkualitas. Pemberian tambahan air leri dengan konsentrasi yang berbeda juga berpengaruh terhadap jumlah tubuh buah jamur merang. Penambahan leri dengan konsentrasi $50 \mathrm{ml}$ lebih banyak jumlah tubuh buah jamurnya dari pada penambahan leri dengan konsentrasi $100 \mathrm{ml}$ dan tanpa penambahan leri. Hal ini dikarenakan jamur merang tumbuh pada kondisi media tanam yang tidak banyak mengandung air tetapi lembab. Apabila media tanam jamur merang terlalu banyak mengandung air maka yang terjadi jamur akan mudah membusuk sebelum berkembang.

\section{Pertumbuhan jamur merang pada mediaEnceng gondok}

Rerata berat tubuh buah jamur merang grafik 1 , menunjukkan berat badan buah terbaik adalah pada perlakuan M3L1 dan M3L2 (enceng gondok $125 \mathrm{~g}$ + leri $50 \mathrm{ml}$ ), yaitu $76,67 \mathrm{~g}$ dan 75,00g, hasil tersenut lebih baik dibandingkan dengan M3L0 yaitu 60,67 g. Enceng gondok dan air leri sangat berpengaruh dalam pertumbuhan berat tubuh buah jamur merang. Hal itu karena kedua bahan tambahan tersebut sama-sama mengandung selulosa dan sama-sama menambah unsur hara dalam pertumbuhan jamur merang, sehingga dapat membantu pertumbuhan berat tubuh jamur merang.

Kandungan nutrien enceng gondok sama dengan rumput gajah, yakni protein kasar 10-14 persen, serat 
kasar 32-47 persen, lemak kasar dan kadar abu sekitar 7-12 persen. Hasil penelitian terdapat perbedaan berat tubuh buahjamur merang satu dengan yang lainnya, hal tersebut terjadi karena factor penambahan nutrisi pada setiap perlakuan pada baglog yang berbeda. Hasil ini di dukung oleh Aini (2013), menyatakan bahwa Penambahan eceng gondok pada media tanam dapat meningkatkan nutrisi yang dibutuhkan oleh jamur, mempunyai pertumbuhan miselium yanglebihcepat, sehinggamempunyai cadangan energi yang cukup untuk menghasilkan berat segar yang optimal. Oleh karena itu, miselium yang telah memenuhi media tanam lebih cepat akan mensuplai nutrisi lebih awal dibandingkan dengan media tanam yang miseliumnyabelum penuh. penambahan eceng gondok lebih banyak memiliki kadar air yang lebih tinggi. Sehingga menyebabkan pertumbuhan miselium lebih lambat. Menurut Nana Dwi Anggraini (2015), penambahan eceng gondok $125 \mathrm{~g}$ dan leri $50 \mathrm{ml}$ menghasilkan berat tubuh buah yang lebih baik dibandingkan dengan penambahan eceng gondok 250 g dan media yang tanpa penambahan air leri maupun yang di tambahkan air leri $100 \mathrm{ml}$.

Eceng gondok dan leri sangat berpengaruh dalam pertumbuhan berat tubuh buah jamur merang karena kedua bahan tambahan tersebut sama-sama mengandung selulosa dan sama-sama menambah unsur hara dalam pertumbuhan jamur merang, sehingga dapat membantu pertumbuhan berat tubuh buah jamur merang.

Penambahan leri dengan konsentrasi $50 \mathrm{ml}$ menghasilkan berat tubuh buah jamur merang yang terbaik dari pada penambahan $100 \mathrm{ml}$ atau tanpa penambahan leri. Hal ini karena media tanam jamur merang tidak memerlukan air yang terlalu banyak, apabila terlalu banyak mengandung air maka akan menyebabkan pembusukan pada jamur.Menurut Fatimah (2008), leri memiliki kandungan mineral, vitamin $\mathrm{B} 1, \mathrm{~B} 12$, unsur hara $\mathrm{N}, \mathrm{P}, \mathrm{K}, \mathrm{C}$, zat besi dan fosfor yang baik dipakai untuk nutrisi dalam budidaya jamur merang.

Pada penelitian ini, media yang digunakan untuk menumbuhkan jamur merang adalah adalah media baglog yang tidak lazim digunakan untuk budidaya jamur merang, yaitu menggunkan bedengan. Kandungan nutrisi pada setiap baglog yang berbeda menyebabkan berat tubuh buah jamur merang tiap baglog berbeda. Menggunakan teknik media tanam yang baru ini, yaitu menanam jamur merang pada baglog diperoleh jamur merang memiliki warna lebih putih, baunya lebih wangi dan kekenyalannya terasa lebih padat. Hasil ini didukung oleh Suharjo (2010) Memanfaatkan kardus bekas menjadi media tanam jamur merang menjadi alternatif bisnis jamur yang dilipih beberapa orang karena jamur merang yang dihasilkan ternyata lebih bagus dan lebih berkualitas jika dibandingkan dengan jamur merang yang ditanam pada bedengan, warnanya tidak lagi bau kotoran hewan, warnanya tidak kusam dan kekenyalannya terasa lebih padat. Hal tersebut agak berbeda dengan jamur yang dikembangkan melalui media merang atau jerami, yang cenderung menghasilkan warna kecokelatan dan berbau agak langu. Meskipun produktivitasnya kurang 
maksimal jika dibandingkan dengan cara bedengan.

Menurut pendapat Adiyuwono (2002), dalam budidaya jamur merang dipengaruhi juga oleh cara penanaman (penebaran) bibit. Para pembudidaya jamur merang pada umumnya melakukan penebaran bibit dengan menaburkan bibit diatas permukaan media, ternyata dengan menaburkan bibit diatas permukaan media tanam belum memberikan hasil yang maksimal, hal ini terlihat bahwa tidak semua titik dari permukaan media tanam jamur merang menghasilkan badan buah. Waktu pemenuhan miselium pada jamur merang yang ditanam pada baglog ini tidak bersamaan, sehingga waktu pemanenan tidak sama dan hasil jumlah tubuh buahnyapun tidak sama pula.

\section{PENUTUP}

\section{Kesimpulan}

Berdasarkan pembahasan dapat diambil kesimpulan sebagai berikut: produksi jamur merang yang ditumbuhkan dalam baglog ditambahkan limbah organik yang terdiri atas klaras, kardus dan enceng gondok, dan leri yang terbaik, yaitu pada perlakuan: $\mathrm{M}_{1} \mathrm{~L}_{2}$ (klaras $125 \mathrm{~g}$ dan penambahan air leri $100 \mathrm{ml}$ ) yaitu $67,51 \mathrm{~g}$, M2L2 (media kardus dengan penambahan air leri $100 \mathrm{ml}$ ) yaitu 75,00 g dan perlakuan M3L1 (enceng gondok $125 \mathrm{~g}$ + leri $50 \mathrm{ml}$ ), yaitu $76,67 \mathrm{~g}$. Sedangkan berat tubuh buah jamur merang paling rendah pada perlakuan $\mathrm{M}_{1} \mathrm{~L}_{0}$, yaitu $61,67 \mathrm{~g}$, M2L0 (media kardus tanpa penambahan air leri) yaitu 56,67 $\mathrm{g}$, dan M3L0 yaitu $60,67 \mathrm{~g}$.

\section{Saran}

Perlu dilakukan penelitian yang membandingkan produktivitas jamur merang secara bedengan dan baglog untuk menguji kualitas jamur merang dan produktifitas jamur merang.

Pemberian air saat pengomposan bila terlalu banyak akan mempengaruhi pertumbuhan jamur merang sehingga pertumbuhan jamur merang menjadi terhambat.

\section{DAFTAR PUSTAKA}

Astawan, Made. 2004. Air Cucian Beras. http://scribd.com/doc/25950862/ Seminar-kimia. Diakses Sabtu, 24 Mei 2014.

Belewu. 2005. Cultivation of mushroom (Volvariella volvacea) on banana leaves. African Journal of Biotechnology Vol. 4 (12), pp. 14011403, December 2005.

Chazali, S. dan P. S. Pratiwi. 2010. Usaha Jamur Tiram Skala Rumah Tangga. Jakarta: Penebar Swadaya.

Chang, S.T. and P.G. Miles. 1987. Edible Mushroom and Their Cultivation. CRC Press. Boca Raton Florida

Houston,D.F. and G.O Kohler, 1982. Nutritional Propertes of Rice. National Academy of Science Washington DC.

Howard RL, et. al. 2003: Lignocellulose biotechnology: issues ofbioconversion and enzyme production. African Journal of Biotechnology, Volume 2, No.12, Page 602-619.

Herlina, Ninuk, dkk. 2010. Kajian Macam Media Tumbuh Terhadap Hasil Jamur Merang (Volvariella volvacea). Jurnal Ilmu Hayati, Volume 22, No.8, Halaman 51-57.Malang: Fakultas Pertanian. Universitas Brawijaya Malang. 
Irawati, Metti, dkk. 1999. Campuran Kapas dan Kelaras Pisang Sebagai Media Tanam Jamur Merang. Jurnal Mikrobiologi Indonesia, Volume 4, No.1, Halaman 27-29. Bogor: Jurusan Biologi FMIPA Institut Pertanian Bogor.

Indriani, Yovita Hety. 1999. Membuat Kompos Secara Kilat. Jakarta: PT. Penebar Swadaya.

Irianto, Yuli. Dkk. 2008. Pertumbuhan, Kandungan Protein, dan Sianida Jamur Kuping (Auricularia polytricha) pada Medium Tumbuh Serbuk Gergaji dan Ampas Tapioka dengan Penambahan Pupuk Urea. Jurnal Bioteknologi, Volume 5, No. 2, Halaman 43-50. Surakarta: Jurusan BiologiFMIPA Universitas Sebelas Maret Surakarta.

Jalaludin, Samul Rizal. 2005. Pembuatan Pulp dari Jerami Padi Menggunakan Natrium Hidroksida. Jurnal Sistem Teknik Indusrti, Volume 6, No.5. Lhokseumawe: Jurusan Teknik Kimia Universitas Malikussalaeh Lhokseumawe.

Kalsum, Ummu, dkk. 2011. Efektifitas Pemberian Air Leri Terhadap Pertumbuhan Dan Hasil Jamur Tiram Putih (Pleurotus ostreatus). Jurnal Agroteknoogi, Volume 4, No.2, Halaman 86-92. Madura: Universitas Trunojoyo.

Mayun, Ida Ayu. 2007. Pertumbuhan Jamur Merang (Volvariella volvaceae) pada Berbagai Media Tumbuh. Jurnal Pertanian, Volume 3, No.3, Halaman 124-128. Denpasar. Fakultas Pertanian Universitas Udayana.

Nurhayati, Arin. 2008. "Efektifitas Penyiraman Ekstrak Kulit Kacang Hijau Dan Air Cucian Beras (Leri) Terhadap Pertumbuhan
Sansiviera trifasciata". (Skripsi S-1 Progdi Biologi). Surakarta: FKIP Universitas Muhammadiyah Surakarta.

Puspaningrum, Indah. 2013. Produksi Jamur Tiram Putih (Pleurotus ostreatus)Pada Media Tambahan Molase Dengan Dosis Yang Berbeda. JurusanPendidikan Biologi. Fakultas Keguruan dan Ilmu Pendidikan. Universitas Muhammadiyah Surakarta.

Puspitarini, Margaret. 2011. Air cucian Beras Bisa Tumbuhkan Tanaman. http://kampus.okezone.com/ read/2011/10/18/372/517127/ air-cucian-beras-bisa-suburkantanaman.html. Diakses Senin, 24 Mei 2014

Setyorini, Anggita Utomo. 2013. "Pengaruh Penambahan Limbah Ampas Tebu Dan Serabut Kelapa Terhadap Produktivitas Jamur Merang (Vovariella volvaceae)" (Skripsi S-1 Progdi Biologi). Surakarta: FKIP Universitas Muhammadiyah Surakarta.

Suhardiman, P, 1980. Jamur Merang dan Mushroom.pusat PenelitianYayasan Sosial Tani Membangun,Jakarta.

Suharjo, Enjo. 2010. Bertanam Jamur Merang di Media Kardus, Limbah Kapas, dan Limbah Pertanian. Jakarta: PT AgroMedia Pustaka.

Sumiati, E, dan Diny Djuariah. 2007. Teknologi Budidaya dan Penanganan Pascapanen Jamur Merang, Volvariella volvacea. Balai Penelitian Tanaman Sayuran. Bandung.

Widiyastuti, B. 2008. Budidaya Jamur Kompos: Jamur Merang, Jamur Kancing. Jakarta: Penebar Swadaya. 
Bioeksperimen

Volume 2 No.2, (September 2016)

ISSN 2460-1365

Yuliani, farida. 2013. Pertumbuhan dan Produksi Jamur Merang (Volvariella volvaceae) yang Ditanam pada Media Jerami, Blotong, dan Ampas Tebu dengan Berbagai Frekwensi Penyiraman. (Skripsi S-1 Fakultas Pertanian). Kudus: UMK.

Zuyasna, Mariani Nasution, dan Dewi Fitriani. 2011. Pertumbuhan dan Hasil JamurMerang Akibat Perbedaan Media Tanam dan Konsentrasi Pupuk Super A-1 (Agroteknologi Fakultas Pertanian). Universitas Syariah Kuala Darussalam. Aceh. 